\title{
Who Writes the Check If the Grounding of VLOC "Stellar Banner" Is Considered a Case of Deviation?
}

\author{
Marcos Aurelio de Arruda \\ Arruda Consulting, Vitória, ES, Brazil \\ Email:marcos@arrudaconsulting.com
}

How to cite this paper: de Arruda, M. A. (2021). Who Writes the Check If the Grounding of VLOC "Stellar Banner" Is Considered a Case of Deviation? Beijing Law Review, 12, 762-767. https://doi.org/10.4236/blr.2021.123040

Received: June 24, 2021

Accepted: August 3, 2021

Published: August 6, 2021

Copyright ( $\odot 2021$ by author(s) and Scientific Research Publishing Inc. This work is licensed under the Creative Commons Attribution International License (CC BY 4.0).

http://creativecommons.org/licenses/by/4.0/

\section{(c) (i) Open Access}

\begin{abstract}
This article tries to enlighten a matter that is the termination of the insurance and cargo contracts after a geographical deviation using the case of the VLOC "MV STELLAR BANNER". The ship voided part of the maritime channel and stranded during her laden voyage in Brazil. After four months grounded, the salvors decided to scuttle the ship, and the cargo was lost. The question that arises is who is going to bear the losses and expenses if a geographical deviation has occurred.
\end{abstract}

\section{Keywords}

“STELLAR BANNER”, Deviation, Marine Insurance, Liability

\section{Introduction}

The VLOC "MV STELLAR BANNER" disregarded the last two pair of buoys of the maritime channel and grounded on a shallow seabed after departing from Ponta da Madeira (Brazil) to Qingdao (China) during her laden voyage with a cargo of 295,000 MT of iron ore.

The salvage contract incorporated and invoked the SCOPIC clause, which would transfer the salvage costs to shipowners in case of either a too onerous or a no cure operation. The salvage operation that lasted four months did not save neither the ship nor her cargo but prevented any damage to the environment.

Diverting voluntarily from the customary route can constitute a geographical deviation. The result of deviation is bringing the cargo and insurance contracts to an end, and consequently shipowners assume the liabilities for ship and cargo's losses and expenses. 
This article tries to discuss who is going to write the check to pay the losses and expenses if the diversion at the maritime channel is considered a deviation.

\section{The Accident}

On February, 24 $4^{\text {th }}, 2020$, VLOC “MV STELLAR BANNER” (300,660 DWT, 2016 Built), left the port of Ponta da Madeira, in Maranhão, Brazil, to Qindao, China, with a cargo of 295,000 MT of iron ore.

Three days later, on February, $27^{\text {th }}$, of 2020 , Polaris Shipping Co. Ltd., from South Korea, press released that one of their ships, VLOC "MV STELLAR BANNER", had reported that...

... "the vessel made contact with an unidentified shallow seabed after departing Ponta da Madeira, Brazil on 24th February at approx. 21:30 hours local time. All crew members are safe, and no water pollution has been reported.

As a result of the incident, some ballast water tanks, and void space suffered damage although the extent of damage to be further established. All cargo holds are believed to be intact, and the situation is under control. In order to assess damage and secure its own safety, the vessel shifted to a safer area. Proper inspections will be carried out by class/underwriter surveyors and a salvage company has been arranged for dealing with the situation. All the appropriate authorities have been reported and are in close contact about the case."

Besides crew's integrity, there were concerns of a likely environmental disaster as there were around 3.000 tons of fuel oil and 140 tons of gas oil on her tanks (Schuler, 2020). Those were promptly discarded as the ship's master and crew have safely disembarked and the "slight oil sheen noticed at the site was confirmed to be residue of 'dead oil' which was on the deck; not leakage from fuel tanks".

Initial information points that VLOC "STELLAR BANNER" did not sail through the last two pairs of buoys of the São Marcos' Bay channel, passing off their starboard side, before touching the "unidentified seabed".

A salvage operation has started after the accident. Following the salvage operation that has lightened around 145,000 $\mathrm{MT}^{1}$ of the cargo, the ship refloated on June $3^{\text {rd }}$. Surveys have confirmed that VLOC "Stellar Banner" was a constructive total loss and could not be safely towed to a shipyard. The actors involved have decided that the best safety option was scuttling the ship, with which the Brazilian environmental and maritime authorities have agreed.

Then, the salvage team prepared the ship for scuttling, removing her loose parts, but decided to leave onboard the remaining cargo (other 150,000 tons of iron ore). On June $12^{\text {th }}$, VLOC "STELLAR BANNER" was tugged and started her last voyage to a 2000 meters depth grave at sea.

${ }^{1}$ The iron ore was confirmed to be incapable of causing harm to human and marine lives, so it was discarded at a dumping spot at sea. 


\section{The Salvage Contract}

Few days after the grounding, Polaris Shipping and Ardent Maritime Netherlands BV and Smit Salvage BV signed a LOF ${ }^{2}$ agreement with SCOPIC both incorporated and invoked.

The salvage reward is based in many issues, but the most relevant is the rule "NO CURE, NO PAY". It means that there is no reward for failure, no matter salvor's effort and expense (International Convention on Salvage, 1989a: Art. $12)^{3}$.

Where there is salved property, those (ship and cargo) who have their salved values are liable for the salvage reward (International Convention on Salvage, 1989b: Art. 13) ${ }^{4}$. That is going to give the salvor a right to a maritime lien on the salved vessel and cargo until the reward is paid. That reward is going to be paid by the hull \& machinery and cargo insurers proportionally to vessel and cargo's salved values.

Where there is no salved value or salvage is too onerous, salvors rely only on compensation clauses (International Convention on Salvage, 1989c: Art. 14) This compensation is entitled from the shipowner and do not give any rights of maritime lien on ship and cargo, which means that the salvors will have difficulty to enforce their reward. To solve that problem, $\mathrm{ISU}^{6}$ and International P \& I Group $^{7}$ agreed a compensation clause named SCOPIC (Special Compensation P \& I Clause) that, once both incorporated and invoked in a LOF agreement, imposes the shipowner the obligation to provide the salvors a security (Special Compensation P \& I Clause, Art 3$)^{8}$ of USD 3 million for the salvage claim?

As VLOC "Stellar Banner" was scuttled and her cargo was lost, there were no ${ }^{2}$ LOF or Lloyd's Open Form or Lloyd's Standard Form of Salvage Agreement (LSSA) is a standard form contract for a marine salvage operation.

${ }^{3}$ International Convention on Salvage, 1989a: Art. 12-1. Salvage operations which have had a useful result give right to a reward. 2. Except as otherwise provided, no payment is due under this Convention if the salvage operations have had no useful result.

${ }^{4}$ International Convention on Salvage, 1989b: Art. 13-[...] 2. Payment of a reward fixed according to paragraph 1 shall be made by all of the vessel and other property interests in proportion to their respective salved values. [...] 3. The rewards, exclusive of any interest and recoverable legal costs that may be payable thereon, shall not exceed the salved value of the vessel and other property.

${ }^{5}$ International Convention on Salvage, 1989c: Art. 14-1. If the salvor has carried out salvage operations in respect of a vessel which by itself or its cargo threatened damage to the environment and has failed to earn a reward under article 13 at least equivalent to the special compensation assessable in accordance with this article, he shall be entitled to special compensation from the owner of that vessel equivalent to his expenses as herein defined.

${ }^{6}$ International Salvage Union. https://www.marine-salvage.com

${ }^{7}$ The thirteen P \& I Clubs which comprise the International Group (the "Group") between them provide marine liability cover (protection and indemnity) for approximately $90 \%$ of the world's ocean-going tonnage. https://www.igpandi.org/about

${ }^{8}$ Special Compensation P \& I Clause, Art 3-The owners of the vessel shall provide to the Contractor within 2 working days (excluding Saturdays and Sundays and holidays usually observed at Lloyd's) after receiving written notice from the contractor invoking the SCOPIC clause, a bank guarantee or P \& I Club letter (hereinafter called "the Initial Security") in a form reasonably satisfactory to the Contractor providing security for his claim for SCOPIC remuneration in the sum of US $\$ 3$ million, inclusive of interest and costs.

${ }^{9}$ That means that if salvors expenses were higher than their reward, shipowner would have to bear the difference. 
salved properties. Then, the only reward to salvors was going to be that granted by SCOPIC, to be paid by the shipowner's P \& I insurance.

The problem appears where a geographical deviation emerges.

\section{Deviation}

\subsection{Definition and Consequences of Deviation}

A ship is bound by the obligation to prosecute the voyage following the usual route (Davis v. Garrett, 1830). Diverting voluntarily from the customary route is a serious breach that does not only increase the risks of the maritime expedition but creates a new one that is different from the contracted voyage (Arruda, 2021). That breach is called "deviation".

The consequences of the deviation are the same around the world: a deviation is a so fundamental breach that gives the innocent party the right either "to accept the repudiation and treat the contract as at an end as from the date of the repudiation" or to waive the deviation, reaffirming the contract (Tate \& Lyle, 1936). Opting for terminating the contract displaces the carriage contract and abrogates the bill of lading exceptions; and invalidates the marine policy (Al-Kabban, 2018). The faulty party loses the benefit of the contract's exception clauses and assumes the liabilities for loss or damage to goods carried.

In Davis v. Garret ${ }^{10}$, the plaintiff contracted a barge to carry a cargo of lime from Kent to London. The defendant deviated to the East Swale and Whitstable Bay, where the vessel and cargo were lost after a storm. The defendant alleged that he had no obligation to take the cargo direct to London, but the court held that:

"We cannot but think that the law does imply a duty in the owner of a vessel, whether a general ship or hired for the special purpose of the voyage, to proceed without unnecessary deviation in the usual and customary course".

(Rogers et al., 2016)

Other case is Joseph Thorley Ltd. v. Orchis S.S. Co. Ltd. $^{11}$. In this case, the ship deviated, but she has arrived safe at the port. However, the stevedores damaged a cargo of locust beans while disembarking it:

"Notwithstanding, there was a clause in the bill of lading excepting the owners for loss caused by stevedores. That exception was debarred as the contract was displaced due to the deviation". (Arruda, 2021)

Another case is Tate \& Lyle, Ltd. v. Hain Steamship Company, Ltd. ${ }^{12}$, the authority in cases of geographical deviation. In this case, the UK Supreme Court has decided that even an insignificant deviation gives the innocent party the right to terminate the contract.

More recently, in "Dera v Derya" (Dera Commercial Estate v Derya Inc.,

${ }^{12}$ [1936] 55 Ll.L.Rep. 159. 
2018), the UK High Court held that a geographical deviation ousted the rights and defenses afforded by the Hague-Visby Rules in a contract of carriage.

\subsection{Deviation Clauses in Vessels' Insurance Contracts}

A ship has basically three insurance policies: hull \& machinery ${ }^{13}$ cargo $^{14}$, and $\mathrm{P}$ $\& \mathrm{I}^{15}$. Those policies covers can essentially tackle any losses or damages a shipowner has during the vessel's maritime endeavor.

At first, we can state that the salvage reward (SCOPIC) would be paid by the $P$ \& I insurer; and the ship and cargo losses would be paid by the hull \& machinery and the cargo insurers, respectively.

Nonetheless, one cannot disregard that marine insurance policies have clauses that deal with deviation: for example: VLOC "STELLAR BANNER"'s P \& I insurance cover is from Britannia P \& $\mathrm{I}^{16}$. The Rule 19-17 of Britannia P \& I's Rule Book of 2020/2021 standard cover clearly states that "there shall be no recovery where the Member has become liable in consequence of a deviation from the contractually agreed voyage unless in the case of a deviation authorized by the Member [...]". Nonetheless, additional insurance covers are available to members as the BREACH OF CONTRACT OF CARRIAGE (DEVIATIONS) that provides cover for "liability to cargo arising out of deviations".

That can affect the salvage contract between Polaris Shipping and Ardent Maritime Netherlands BV and Smit Salvage BV as well. As SCOPIC clause was incorporated and invoked, and ship and cargo were lost, shipowners or their P \& I Club are going to bear the salvage costs. If there was a deviation from the agreed route, the P \& I contract were terminated, then shipowners are going to be liable for salvage expenses.

Hull \& machinery and cargo insurance policies have analogous statements regarding to deviation: standard insurance policies states that there is no cargo damage or loss cover in cases of deviation, unless insurer is promptly advised and the cargo is held covered on terms to be agreed, or there is an additional insurance cover ${ }^{17}$.

\section{Conclusion}

Marine insurance is essential to maritime business, and there is no doubt that the huger losses and expenses, in VLOC "STELLAR BANNER"'s accident, are the vessel herself, the cargo, and the salvage award.

${ }^{13} \mathrm{Hull}$ and Machinery (H \& M) insurance covers physical loss of or damage to the hull and the machinery onboard.

${ }^{14}$ Marine Cargo insurance covers the loss or damages caused to marine cargo during the transit.

${ }^{15} \mathrm{P} \&$ I Insurance cover "shipowners, operators, and charterers for third-party liabilities [...]. The main risks covered are liabilities, expenses, and costs for: loss of life, injury and illness of crew, cargo loss, shortage or damage, collision [...]" It is distinguished from ordinary marine insurance in that it is based on the not-for-profit principle of mutuality where members of the club are both the insurers and the insureds [...]". https://www.american-club.com/page/protection-indemnity-insurance ${ }^{16} \mathrm{https} / /$ www.handybulk.com/polaris-shipping/.

${ }^{17}$ https://www.tokiomarine-nichido.co.jp/hojin/marine_site/senpaku/covenant/pdf/hull_insurance_c lause_20210-401.pdf, and http://www.susep.gov.br/download/menubiblioteca/SeguroTransporte.pdf. 
Where everything comes up roses, insurance is going to pay all the losses and expenses, but the problems start where a geographic deviation emerges.

As a ship is bound by the obligation to follow the customary route since Davis v. Garret and diverting from the maritime channel is a serious breach that gives the innocent party (the cargo owner and the insurers) the right to terminate the contract. Where that happens, the faulty party becomes liable for expenses, losses and damages to the goods carried.

Assuming the master of VLOC "STELLA BANNER"' voluntarily did not follow the prescribed maritime channel means that the ship has deviated, and the cargo and insurance contracts terminated. Thus, Polaris Shipping Co. Ltd. would become the de facto insurer of the cargo, the vessel and third parties' liabilities.

\section{Conflicts of Interest}

The author declares no conflicts of interest regarding the publication of this paper.

\section{References}

Al-Kabban, R. A. M. (2018). The Effect of Deviation Occurring in the Course of a Maritime Voyage on the Liability of the Carrier Under the Hague/Visby Rules and Hamburg Rules, in Relation to Certain Countries (p. 38). Glasgow: University of Glasgow. http://theses.gla.ac.uk/2758/1/1988alkabbanphd.pdf

Arruda, M. A. (2021). The Theory of Contract and the Doctrine of Deviation (p. 56, 68). Curitiba.

Davis v. Garrett (1830). 6 Bing 716.

Dera Commercial Estate v Derya Inc. (2018). EWHC 1673 (Comm).

International Convention on Salvage (1989a). Art. 12.

International Convention on Salvage (1989b). Art. 13.

International Convention on Salvage (1989c). Art. 14.

Rogers, A., Chuah, J., \& Dockray, M. (2016). Cases and Materials on the Carriage of Goods by Sea (pp. 63-64, 4th ed.). Routledge. https://doi.org/10.4324/9781315749754

Schuler, M. (2020). Stellar Banner Update: De-Bunkering Plan Submitted for Review [Images].

https:/gcaptain.com/stellar-banner-update-de-bunkering-plan-submitted-for-review-i mages/

Special Compensation P \& I Clause, Art. 3.

https://assets.lloyds.com/assets/pdf-scopic-2020/1/SCOPIC-2020.pdf

Tate \& Lyle (1936). Ltd. v. Hain Steamship Company, Ltd. 55 Ll.L.Rep. 159. 